[Regular Paper]

\title{
Effects of Metal Oxide Support and Non-noble Metal Active Species on Catalytic Steam Reforming of Ethanol for Hydrogen Production
}

\author{
Takanori SAEKI, Hironobu OHKITA, Noriyoshi KAKUTA, and Takanori MizuSHIMA* \\ Dept. of Environmental and Life Sciences, Toyohashi University of Technology, \\ 1-1 Hibarigaoka, Tempaku-cho, Toyohashi, Aichi 441-8580, JAPAN
}

(Received March 10, 2015)

\begin{abstract}
Dependence of hydrogen production via the catalytic steam reforming of ethanol on the metal oxide support and first row transition metal catalyst was investigated. Ni supported on $\mathrm{CeO}_{2}$ was more easily reduced and began to produce hydrogen at a lower temperature than $\mathrm{Ni}$ supported on $\mathrm{ZrO}_{2}, \mathrm{SiO}_{2}, \mathrm{Al}_{2} \mathrm{O}_{3}$, and $\mathrm{MgO}$. $\mathrm{Ni} / \mathrm{CeO}_{2}$ also maintained a high activity at a constant reaction temperature of $673 \mathrm{~K}$ and inhibited carbon deposition. Therefore, $\mathrm{CeO}_{2}$ was adopted as the catalytic support. Compared with $\mathrm{Ni} / \mathrm{CeO}_{2}, \mathrm{Fe} / \mathrm{CeO}_{2}$ and $\mathrm{Mn} / \mathrm{CeO}_{2}$ were less active. Contrarily, $\mathrm{Co} / \mathrm{CeO}_{2}$ was slightly less active at $673 \mathrm{~K}$, but exhibited a comparable hydrogen yield at $873 \mathrm{~K}$. The $\mathrm{Cu} / \mathrm{CeO}_{2}$ system was reduced more readily and produced hydrogen at a lower temperature, but its activity gradually deteriorated by carbon deposition. Thus we concluded that $\mathrm{Ni} / \mathrm{CeO}_{2}$ exhibited the best combination of properties with the highest hydrogen yield at $673 \mathrm{~K}$ and a long stability.
\end{abstract}

\section{Keywords}

Ethanol steam reforming, Metal oxide support, Transition metal catalyst, Carbon deposition

\section{Introduction}

Hydrogen demand is expected to increase precipitously for fuel cells in the near future. Currently, hydrogen is mainly produced by steam reforming of fossil fuels such as natural gas and petroleum. However, there are environmental concerns associated with this technology: emission of $\mathrm{CO}_{2}$ as a greenhouse gas, resource depletion, destruction of nature due to drilling, etc. Recently, biomass ethanol has attracted significant attention as an alternative resource for hydrogen production $^{1) \sim 3)}$. It is a renewable and environmentallyfriendly fuel because it can be produced by fermenting sugars, starches, and celluloses in plants and the $\mathrm{CO}_{2}$ released during its combustion is reused for the growth of the plants.

Steam reforming of ethanol (SRE):

$$
\mathrm{C}_{2} \mathrm{H}_{5} \mathrm{OH}+3 \mathrm{H}_{2} \mathrm{O} \rightarrow 2 \mathrm{CO}_{2}+6 \mathrm{H}_{2}
$$

is the most promising method for converting biomass ethanol to hydrogen ${ }^{2)}$ 7). It differs principally from the steam reforming of methanol (SRM), which is used in methanol-converting fuel cells, because it involves the cleavage of a $\mathrm{C}-\mathrm{C}$ bond. $\mathrm{Cu}$ is an excellent catalyst for $\mathrm{SRM}^{8) \sim 10)}$, but is relatively inactive for SRE

DOI: dx.doi.org/10.1627/jpi.58.341

* To whom correspondence should be addressed.

* E-mail: mizushima@ens.tut.ac.jp because of its poor ability to mediate $\mathrm{C}-\mathrm{C}$ bond breaking. In addition, the reaction pathway for SRE is more complicated, and many side reactions may occur ${ }^{2}$.

According to literature ${ }^{2), 3), 5), 11) \sim 18)}, \mathrm{Co}, \mathrm{Ni}, \mathrm{Pd}, \mathrm{Rh}$, and $\mathrm{Pt}$ have catalytic activity for SRE. In particular, $\mathrm{Co}$ and $\mathrm{Ni}$ have been extensively investigated because of their high activities and low cost. It is well known that the catalytic activity and stability of $\mathrm{Co}$ and $\mathrm{Ni}$ are highly dependent on the support ${ }^{3), 13), 15), 19) \sim 21)}$. Sun et al. ${ }^{13)}$ reported that $\mathrm{Ni} / \mathrm{Al}_{2} \mathrm{O}_{3}$ exhibited lower activity for SRE than $\mathrm{Ni} / \mathrm{Y}_{2} \mathrm{O}_{3}$ and $\mathrm{Ni} / \mathrm{La}_{2} \mathrm{O}_{3}$. Alberton et al. ${ }^{19}$ ) also found that a $\gamma-\mathrm{Al}_{2} \mathrm{O}_{3}$-supported $\mathrm{Ni}$ catalyst was more active for $\mathrm{H}_{2}$ production than the catalyst supported on $\alpha-\mathrm{Al}_{2} \mathrm{O}_{3}$. However, activation with a $\mathrm{CH}_{4} / \mathrm{O}_{2}$ mixture significantly increased the stability of $\mathrm{Ni} / \alpha-\mathrm{Al}_{2} \mathrm{O}_{3}$ compared with that observed during standard activation using hydrogen reduction. The increased stability was attributed to the migration of $\mathrm{Ni}$ particles on carbon filaments during $\mathrm{CH}_{4} / \mathrm{O}_{2}$ activation. The effect of modification of the metal in $\mathrm{Ni} / \mathrm{Al}_{2} \mathrm{O}_{3}$ on the SRE was examined by Sanchez-Sanchez et al. ${ }^{20)}$, who demonstrated that a $\mathrm{Ni}$ catalyst supported on $\mathrm{Mg}$-modified $\mathrm{Al}_{2} \mathrm{O}_{3}$ exhibited higher reforming activity due to the lower acidity and enhanced $\mathrm{Ni}$ dispersion in the modified system. They also found that $\mathrm{Ce}$ and $\mathrm{Zr}$ promoted water adsorption/dissociation on $\mathrm{Ni}-\mathrm{Ce}$ and $\mathrm{Ni}-\mathrm{Zr}$ interfaces for improved catalytic activity, and $\mathrm{La}$ and $\mathrm{Ce}$ additives prevented the formation of fibrous carbon deposits on Ni surfaces. 
Table 1 BET Surface Areas of the Supports and Supported Ni Catalysts and the Amount of Deposited Carbon after SRE at $673 \mathrm{~K}$ and $873 \mathrm{~K}$ for $9 \mathrm{~h}$

\begin{tabular}{lccccc}
\hline & \multicolumn{2}{c}{ Surface area $\left[\mathrm{m}^{2} \mathrm{~g}^{-1}\right]$} & & \multicolumn{2}{c}{ Carbon deposit $\left[\mathrm{g} \mathrm{g-cat}^{-1}\right]$} \\
\cline { 2 - 3 } \cline { 5 - 6 } & Unloaded & Ni-loaded & & SRE at $673 \mathrm{~K}$ & SRE at $873 \mathrm{~K}$ \\
\hline $\mathrm{CeO}_{2}$ & 110 & 100 & & 0.21 & 0.28 \\
$\mathrm{ZrO}_{2}$ & 30 & 40 & & 0.65 & 1.21 \\
$\mathrm{SiO}_{2}$ & 300 & 200 & & 0.93 & 2.37 \\
$\mathrm{Al}_{2} \mathrm{O}_{3}$ & 240 & 150 & & 0.07 & 0.24 \\
$\mathrm{MgO}$ & 10 & 60 & & 0.07 & 0.10 \\
\hline
\end{tabular}

The goal of the present study was to determine the best combination of catalytically-active component and support for low-temperature SRE. First, the crystalline structures, reduction properties, catalytic activities, and carbon deposits of $\mathrm{Ni}$ catalysts supported on $\mathrm{CeO}_{2}$, $\mathrm{SiO}_{2}, \mathrm{ZrO}_{2}, \mathrm{Al}_{2} \mathrm{O}_{3}$, and $\mathrm{MgO}$ were investigated to elucidate the effects of the support on SRE. The results of this analysis indicated that $\mathrm{CeO}_{2}$ as a support provided catalysts with high activity at lower temperatures and inhibited carbon deposition. The activities of different $\mathrm{CeO}_{2}$-supported first row transition metals $(\mathrm{Ni}, \mathrm{Co}, \mathrm{Cu}$, $\mathrm{Fe}$, and $\mathrm{Mn}$ ) as catalysts for SRE were evaluated.

\section{Experimental}

\section{1. Catalyst Preparation}

Nine supported catalysts $\left(\mathrm{Ni} / \mathrm{CeO}_{2}, \mathrm{Ni} / \mathrm{ZrO}_{2}, \mathrm{Ni} /\right.$ $\mathrm{SiO}_{2}, \mathrm{Ni} / \mathrm{Al}_{2} \mathrm{O}_{3}, \mathrm{Ni} / \mathrm{MgO}, \mathrm{Co} / \mathrm{CeO}_{2}, \mathrm{Cu} / \mathrm{CeO}_{2}, \mathrm{Fe} / \mathrm{CeO}_{2}$, and $\mathrm{Mn} / \mathrm{CeO}_{2}$ ) were prepared in this study. The precursors of the transition metals were commercial $\mathrm{Ni}\left(\mathrm{NO}_{3}\right)_{2} \cdot 6 \mathrm{H}_{2} \mathrm{O}, \mathrm{Co}\left(\mathrm{NO}_{3}\right)_{2} \cdot 6 \mathrm{H}_{2} \mathrm{O}, \mathrm{Cu}\left(\mathrm{NO}_{3}\right)_{2} \cdot 3 \mathrm{H}_{2} \mathrm{O}$, $\mathrm{Fe}\left(\mathrm{NO}_{3}\right)_{3} \cdot 9 \mathrm{H}_{2} \mathrm{O}$, and $\mathrm{Mn}\left(\mathrm{NO}_{3}\right)_{2} \cdot 6 \mathrm{H}_{2} \mathrm{O}$ (Kishida Chemical). Commercial $\mathrm{ZrO}_{2}$ (Wako Pure Chemical Industries), $\mathrm{SiO}_{2}$ (Nippon Aerosil), $\gamma-\mathrm{Al}_{2} \mathrm{O}_{3}$ (Nippon Light Metal), and $\mathrm{MgO}$ (Kishida Chemical) were also used as catalytic supports. $\mathrm{CeO}_{2}$ was prepared via a precipitation method with urea ${ }^{22)} \mathrm{Ce}\left(\mathrm{NO}_{3}\right)_{3} \cdot 6 \mathrm{H}_{2} \mathrm{O}$ $(11.9 \mathrm{~g})$ and urea $(50 \mathrm{~g})$ were dissolved in water $(500 \mathrm{~mL})$ and stirred at $363 \mathrm{~K}$ for $24 \mathrm{~h}$. After filtration, washing with water, and drying at $383 \mathrm{~K}$ for $12 \mathrm{~h}$, the obtained precipitate was calcined at $773 \mathrm{~K}$ for $5 \mathrm{~h}$. The BET surface areas of the supports are summarized in Table 1.

Each catalyst was prepared by impregnating the support powder with an aqueous solution of the metal nitrate, followed by evaporation to dryness. Each obtained powder was dried at $383 \mathrm{~K}$ for $12 \mathrm{~h}$ and then calcined at $773 \mathrm{~K}$ for $3 \mathrm{~h}$, and the metal loading was adjusted to $10 \mathrm{wt} \%$.

\section{2. Characterization}

X-ray diffraction (XRD) patterns were obtained using a Rigaku Rint2000 diffractometer with Ni-filtered $\mathrm{Cu} \mathrm{K}_{\alpha}$ radiation generated at an accelerating voltage of $30 \mathrm{kV}$ and a tube current of $30 \mathrm{~mA}$. Specific surface areas were estimated by applying the BET theory to the nitrogen adsorption isotherms determined at liquid nitrogen temperature. The temperature programmed reduction (TPR) was determined by heating the sample at a rate of $10 \mathrm{~K} \mathrm{~min}^{-1}$ in a flow of $10 \% \mathrm{H}_{2} / \mathrm{Ar}$. The amount of $\mathrm{H}_{2}$ consumed was detected by a thermal conductivity detector. The quantity and combustion properties of the carbon deposited on the catalyst during the reaction were evaluated via thermogravimetry (TG) using a Rigaku TG8120 Thermo Plus Evo. The catalyst was heated at a rate of $10 \mathrm{~K} \mathrm{~min}^{-1}$ in air. The carbon amount was calculated by assuming that the weight loss in the TG profile was caused only by combustion of the carbon deposits. In addition, the weight increase due to reoxidation of the catalysts was ignored because it was not detected by TG. The carbon deposits were also observed via field emission scanning electron microscopy (FE-SEM, Hitachi High-Technologies S-4800).

\section{3. Activity Test}

Catalytic activity was evaluated in two types of reactions: temperature-programmed SRE (TP-SRE) with a stepwise temperature increase of $50 \mathrm{~K}$ per $30 \mathrm{~min}$ from 473 to $873 \mathrm{~K}$ and isothermal SRE at $673 \mathrm{~K}$ and $873 \mathrm{~K}$. For each reaction, the unreduced catalyst $(0.2 \mathrm{~g})$ was loaded into a tubular quartz reactor (i.d. $8 \mathrm{~mm}$ ). No reduction pretreatment was carried out because although it shortened the time needed for the catalyst activation, it had little influence on $\mathrm{SRE}$ in the steady state. A mixed solution of $\mathrm{H}_{2} \mathrm{O} / \mathrm{C}_{2} \mathrm{H}_{5} \mathrm{OH}$ with a molar ratio of $3: 1$ was fed at $30 \mu \mathrm{L} \mathrm{min}{ }^{-1}$, vaporized at the top of the reactor, and then sent to the catalyst bed with nitrogen flow of $30 \mathrm{~mL} \mathrm{~min}{ }^{-1}$. The gaseous products were passed through an ice-chilled trap in order to remove any liquids and then analyzed using two gas chromatograms with thermal conductivity detectors, one equipped with a column packed with $13 \mathrm{X}$ molecular sieve and nitrogen as the carrier gas for $\mathrm{H}_{2}$ detection and the other with a column packed with active carbon and helium as the carrier gas for $\mathrm{C} 1$ gases $\left(\mathrm{CO}, \mathrm{CO}_{2}\right.$, and $\left.\mathrm{CH}_{4}\right)$. The product yields $Y\left(\mathrm{H}_{2}\right)$ and $Y(\mathrm{C} 1)$ were calculated according to the ideal SRE equation (Eq. (1)) as follows:

$$
Y\left(\mathrm{H}_{2}\right)(\%)=\frac{F\left(\mathrm{H}_{2}\right)}{6 \times F\left(\mathrm{C}_{2} \mathrm{H}_{5} \mathrm{OH}\right)} \times 100
$$






(a) $\mathrm{CeO}_{2^{-}}$, (b) $\mathrm{ZrO}_{2^{-}}$, (c) $\mathrm{SiO}_{2^{-}}$, (d) $\mathrm{Al}_{2} \mathrm{O}_{2^{-}}$, and (e) $\mathrm{MgO}$-supported $\mathrm{Ni}$ catalysts (1) before and (2) after SRE at $673 \mathrm{~K}$ and (3) $873 \mathrm{~K}$ for $9 \mathrm{~h}$. The marks in the parentheses represent overlaps with XRD peaks due to the supports.

Fig. 1 XRD Patterns of the Supported Ni Catalysts before and after SRE

$$
Y(\mathrm{Cl})(\%)=\frac{F(\mathrm{Cl})}{2 \times F\left(\mathrm{C}_{2} \mathrm{H}_{5} \mathrm{OH}\right)} \times 100
$$

where $F\left(\mathrm{C}_{2} \mathrm{H}_{5} \mathrm{OH}\right)$ represents the feed rate of $\mathrm{C}_{2} \mathrm{H}_{5} \mathrm{OH}$ in mol $\mathrm{min}^{-1}$ and $F\left(\mathrm{H}_{2}\right)$ and $F(\mathrm{C} 1)$ represent the quantities of $\mathrm{H}_{2}$ and $\mathrm{C} 1$ gases produced in $\mathrm{mol} \mathrm{min}^{-1}$, respectively. The quantitative determination of ethanol and liquid products in the trap was difficult because of a poor sensitivity of the gas chromatogram, and therefore the catalytic performance was evaluated via $Y\left(\mathrm{H}_{2}\right)$ and $Y(\mathrm{C} 1)$ in the present investigation.

\section{Results and Discussion}

\section{1. Effect of the Support on SRE over Ni Catalysts}

\section{1. 1. Characterization of the Supported Ni Catalysts before SRE}

XRD patterns of the as-prepared Ni catalysts are shown in Fig. 1. The unmarked peaks in the figure are due to the catalytic supports. No XRD peak due to the $\mathrm{Ni}$ species was observed for $\mathrm{Ni} / \mathrm{MgO}$ (Fig. 1(e) 1). The other catalysts exhibited reflections for the (111), (200), and (220) lattice planes of $\mathrm{NiO}$ crystals at $37.3^{\circ}$, $43.3^{\circ}$, and $62.9^{\circ}$, respectively. The peaks observed for $\mathrm{Ni} / \mathrm{SiO}_{2}$ (Fig. 1(c) 1) were relatively intense. In con-

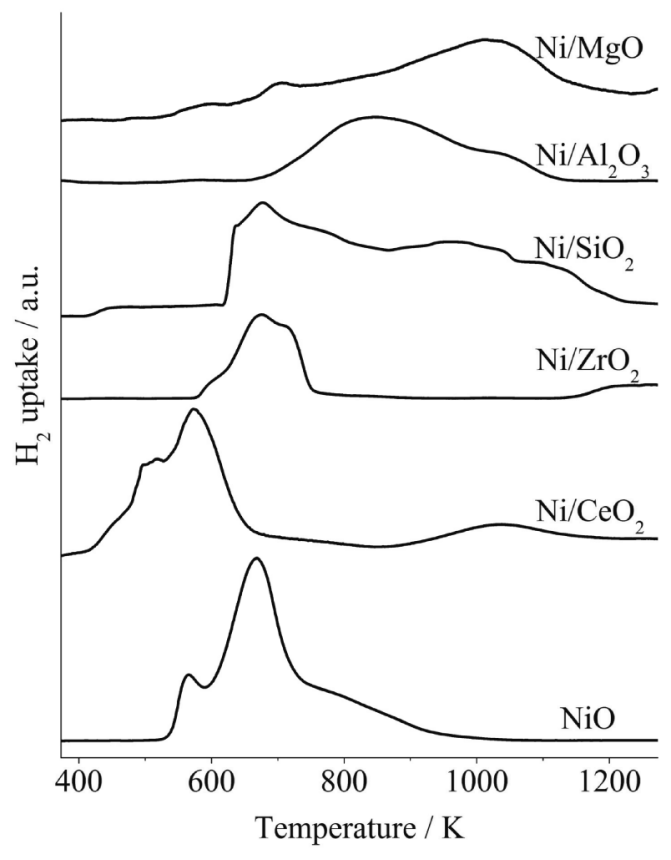

Fig. 2 TPR Profiles of the Supported Ni Catalysts and NiO Powder

trast, the XRD pattern for $\mathrm{Ni} / \mathrm{Al}_{2} \mathrm{O}_{3}$ (Fig. 1(d) 1) consisted of exceedingly weak peaks, indicating very high dispersion of $\mathrm{NiO}$.

The surface areas of the catalysts are summarized in Table 1. The $\mathrm{CeO}_{2-}, \mathrm{SiO}_{2-}$, and $\mathrm{Al}_{2} \mathrm{O}_{3}$-supported catalysts had smaller surface areas than the unloaded supports, and those of $\mathrm{ZrO}_{2}$ and $\mathrm{MgO}$ increased after metal loading. In particular, $\mathrm{Ni} / \mathrm{MgO}$ had 6 times the surface area of the raw $\mathrm{MgO}$. This extraordinary increase suggests partial dissolution of the $\mathrm{MgO}$ surface during Ni loading.

Figure 2 shows the TPR profiles of the Ni catalysts and $\mathrm{NiO}$ powder as a reference. The $\mathrm{NiO}$ crystallites supported on $\mathrm{ZrO}_{2}$ were reduced at approximately $673 \mathrm{~K}$, which was nearly the same as that for the unsupported $\mathrm{NiO}$. $\mathrm{Ni} / \mathrm{SiO}_{2}$ also provided a peak maximum at the same temperature, but $\mathrm{H}_{2}$ consumption continued beyond $900 \mathrm{~K}$. The higher-temperature peak is likely due to the reduction of $\mathrm{Ni}^{2+}$ ions from surface nickel philosilicates $^{23)}$.

$\mathrm{Ni} / \mathrm{CeO}_{2}$ was reduced at approximately $100 \mathrm{~K}$ lower than $\mathrm{NiO}$, indicating that $\mathrm{CeO}_{2}$ promoted the reduction of $\mathrm{NiO}$ to the metal. In contrast, $\mathrm{Ni} / \mathrm{Al}_{2} \mathrm{O}_{3}$ and $\mathrm{Ni}$ / $\mathrm{MgO}$ exhibited reduction peaks at higher temperatures. The broad peak with a maximum at $845 \mathrm{~K}$ and a shoulder peak at approximately $1030 \mathrm{~K}$ observed for $\mathrm{Ni} /$ $\mathrm{Al}_{2} \mathrm{O}_{3}$ is attributed to the reductions of $\mathrm{NiO}$ species weakly interacting with the $\mathrm{Al}_{2} \mathrm{O}_{3}$ support and of a diluted $\mathrm{NiAl}_{2} \mathrm{O}_{4}$-like phase, respectively ${ }^{20)}$. In the spectrum of $\mathrm{Ni} / \mathrm{MgO}$, the percentage of the highertemperature peak was much larger than that for the other materials. Considering the absence of XRD peaks due 


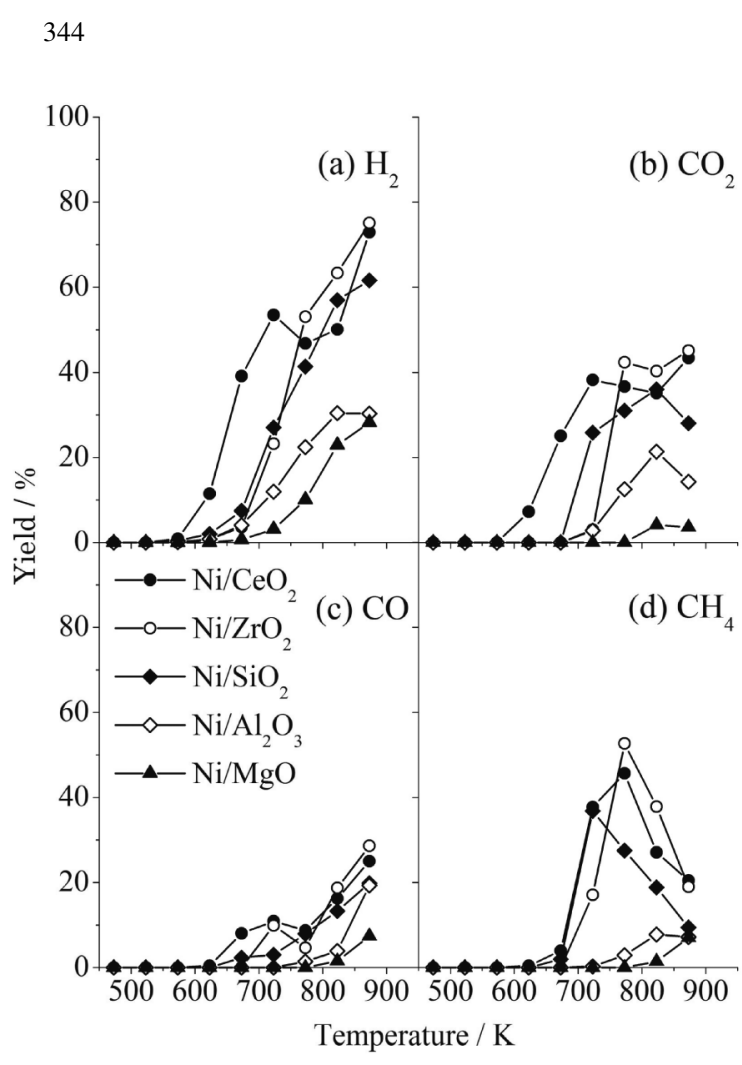

Fig. 3 Product Yields for Temperature-programmed SRE over the Supported Ni Catalysts

to $\mathrm{Ni}$ species and the marked increase in surface area following $\mathrm{Ni}$ loading, this behavior is attributed to the reduction of $\mathrm{Ni}^{2+}$ ions located more deeply in the $\mathrm{MgO}$ bulk (NiO-MgO solid solution) $)^{24) \sim 26)}$.

\section{1. 2. SRE over the Supported Ni Catalysts}

The yields of $\mathrm{H}_{2}, \mathrm{CO}_{2}, \mathrm{CO}$, and $\mathrm{CH}_{4}$ during TP-SRE over the $\mathrm{Ni}$ catalysts on various supports are shown in Fig. 3. $\mathrm{Ni} / \mathrm{CeO}_{2}$ began to produce $\mathrm{H}_{2}$ and $\mathrm{CO}_{2}$ at $623 \mathrm{~K}$, and the other catalysts required higher temperatures for initiation of the reaction. In the temperature range below $750 \mathrm{~K}$, the $\mathrm{H}_{2}$ yield decreased in the order $\mathrm{Ni} / \mathrm{CeO}_{2}>\mathrm{Ni} / \mathrm{SiO}_{2} \approx \mathrm{Ni} / \mathrm{ZrO}_{2}>\mathrm{Ni} / \mathrm{Al}_{2} \mathrm{O}_{3}>\mathrm{Ni} / \mathrm{MgO}$, which was in agreement with the order of the reduction temperature (Fig. 2). These results indicated that the catalytically active phase consists of metallic Ni crystallites.

In the case of $\mathrm{Ni} / \mathrm{CeO}_{2}$, the $\mathrm{H}_{2}$ yields initially increased with increasing temperature then decreased at $773 \mathrm{~K}$, at which point the $\mathrm{CH}_{4}$ yield reached a maximum, and then increased again with a decrease in the $\mathrm{CH}_{4}$ yield. These results suggest that it is important to suppress $\mathrm{CH}_{4}$ production to achieve higher $\mathrm{H}_{2}$ yields. A relatively large quantity of $\mathrm{CH}_{4}$ was also generated over the $\mathrm{ZrO}_{2}$ - and $\mathrm{SiO}_{2}$-supported catalysts, which exhibited $\mathrm{H}_{2}$ yields nearly equivalent to those for $\mathrm{Ni} / \mathrm{CeO}_{2}$ above $750 \mathrm{~K}$. On the other hand, $\mathrm{Ni} / \mathrm{Al}_{2} \mathrm{O}_{3}$ and $\mathrm{Ni} /$ $\mathrm{MgO}$ exhibited relatively low activities over the entire temperature range.

Figure 4 shows the product yields at $9 \mathrm{~h}$ after the

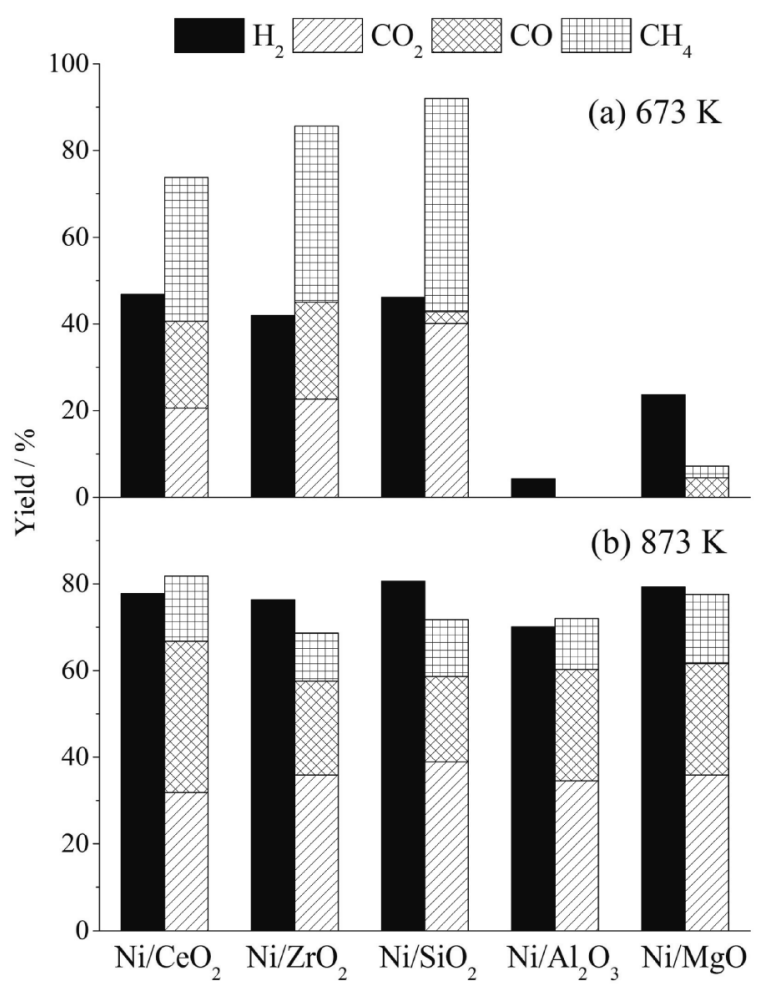

Fig. 4 Product Yields at $9 \mathrm{~h}$ after the Initiation of SRE at (a) $673 \mathrm{~K}$ and (b) $873 \mathrm{~K}$ over the Supported Ni Catalysts

initiation of SRE at $673 \mathrm{~K}$ and $873 \mathrm{~K}$. Although the $\mathrm{H}_{2}$ yields at $673 \mathrm{~K}$ in TP-SRE (Fig. 3(a)) over the $\mathrm{ZrO}_{2}-$ and $\mathrm{SiO}_{2}$-supported catalysts were less than $10 \%$, those for SRE at a constant temperature of $673 \mathrm{~K}$ were constant at approximately $40 \%$, which was comparable to that for the $\mathrm{CeO}_{2}$-supported catalyst. These three catalysts produced $\mathrm{C} 1$ gases with a total yield of more than $70 \%$, approximately half of which was $\mathrm{CH}_{4}$. Raising the reaction temperature to $873 \mathrm{~K}$ resulted in a decrease in $\mathrm{CH}_{4}$ production and an increase in $\mathrm{H}_{2}$ generation.

On the other hand, barely reducible $\mathrm{Ni} / \mathrm{Al}_{2} \mathrm{O}_{3}$ and $\mathrm{Ni} /$ $\mathrm{MgO}$ exhibited much lower $\mathrm{H}_{2}$ and $\mathrm{C} 1$-gas yields at $673 \mathrm{~K}$. However, their activities significantly increased and the clear differences between the supports disappeared at $873 \mathrm{~K}$, which was different from the results in Fig. 3. The fact that higher yields were obtained for the isothermal SRE reaction than TP-SRE indicates that the reduction of the $\mathrm{Ni}$ species during the latter was incomplete, and a larger amount of catalytically-active metal sites were generated in the former at the same temperature over a longer reaction time.

\section{1. 3. Characterization of the Supported Ni Catalysts after SRE}

XRD patterns of the catalysts after SRE at $673 \mathrm{~K}$ and $873 \mathrm{~K}$ are also shown in Fig. 1 ((a) 2-(e) 2 and (a) 3-(e) 3, respectively). The peaks due to NiO crystallites on the $\mathrm{CeO}_{2}$ and $\mathrm{SiO}_{2}$ supports decreased in intensity, and very small peaks for $\mathrm{Ni}(111)$ reflections 


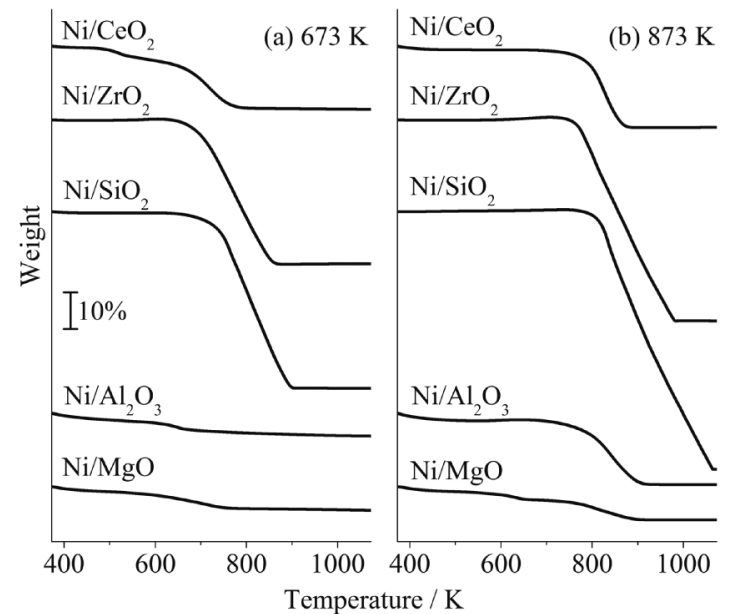

Fig. 5 TG Profiles of the Supported Ni Catalysts after SRE at (a) $673 \mathrm{~K}$ and (b) $873 \mathrm{~K}$ for $9 \mathrm{~h}$

appeared at approximately $44.5^{\circ}$ after SRE at $673 \mathrm{~K}$ (Figs. 1(a) 2 and (c) 2, respectively), indicating the partial reduction of $\mathrm{NiO}$ to metallic Ni. Despite the absence of XRD peaks due to Ni metal, the NiO peaks in the XRD patterns for $\mathrm{Ni} / \mathrm{ZrO}_{2}$ after reaction at $673 \mathrm{~K}$ (Fig. 1(b) 2) were also less intense than those in the pattern for the catalyst before reaction (Fig. 1(b) 1). $\mathrm{Ni} / \mathrm{ZrO}_{2}$ exhibited catalytic activity comparable with that of $\mathrm{Ni} / \mathrm{CeO}_{2}$ and $\mathrm{Ni} / \mathrm{SiO}_{2}$ (Fig. 4(a)), and it is therefore considered that the $\mathrm{NiO}$ on $\mathrm{ZrO}_{2}$ was also partially reduced to form small metal particles as catalytically active species at $673 \mathrm{~K}$. At $873 \mathrm{~K}$, the $\mathrm{NiO}$ crystallites on these three catalysts were completely reduced to $\mathrm{Ni}$ metal, as can be seen in Figs. 1(a) 3-(c) 3 .

The XRD pattern of $\mathrm{Ni} / \mathrm{Al}_{2} \mathrm{O}_{3}$ remained nearly unchanged after SRE at $673 \mathrm{~K}$ (Fig. 1(d) 2), but the reduction of $\mathrm{NiO}$ to $\mathrm{Ni}$ metal was observed at $873 \mathrm{~K}$ (Fig. 1(d) 3). In contrast, no indication of Ni reduction was detected for $\mathrm{Ni} / \mathrm{MgO}$, even at $873 \mathrm{~K}$ (Fig. 1(e) 3). Nevertheless, it is assumed that part of the Ni was reduced, because $\mathrm{Ni} / \mathrm{MgO}$ exhibited high catalytic activity at $873 \mathrm{~K}$ (Fig. $4(\mathbf{b}))$ and $\mathrm{H}_{2}$ consumption was observed below $873 \mathrm{~K}$ during TPR (Fig. 2).

In addition to the peaks due to Ni metal and the support, a new XRD peak appeared at $26.0^{\circ}$ in the XRD patterns shown in Figs. 1(b) 3, (c) 3, and (d) 3. This peak indicates the formation of graphite-like carbon on the $\mathrm{ZrO}_{2-}, \mathrm{SiO}_{2^{-}}$, and $\mathrm{Al}_{2} \mathrm{O}_{3}$-supported catalysts during $\mathrm{SRE}$ at $873 \mathrm{~K}$. In particular, the XRD pattern for Ni/ $\mathrm{SiO}_{2}$ contained an extremely intense peak (Fig. 1(c) 3), which was also detected at $673 \mathrm{~K}$ (Fig. 1(c) 2).

The quantity of carbon deposited after a reaction time of $9 \mathrm{~h}$ was determined via TG analysis in air. The profiles are shown in Fig. 5, and the quantities of carbon estimated from the weight losses during combustion are summarized in Table $\mathbf{1}$. It was found from Fig. 5 that the carbon deposited on the catalysts during
SRE at $673 \mathrm{~K}$ began to burn in the temperature range $660-740 \mathrm{~K}$, and the carbon formed at $873 \mathrm{~K}$ required higher ignition temperatures (750-810 K). Furthermore, the quantity of deposited carbon increased with increasing reaction temperature for all of the catalysts. These results suggest the formation of burnresistant graphite at a higher temperature.

Notably, while $\mathrm{Ni} / \mathrm{CeO}_{2}$ had comparable catalytic activities at $673 \mathrm{~K}$ and $873 \mathrm{~K}$ to those of $\mathrm{Ni} / \mathrm{ZrO}_{2}$ and $\mathrm{Ni} / \mathrm{SiO}_{2}$, much less carbon was deposited on the $\mathrm{Ni} /$ $\mathrm{CeO}_{2}$ catalyst, indicating an inhibiting effect of $\mathrm{CeO}_{2}$ on carbon deposition. In contrast, $\mathrm{Ni} / \mathrm{SiO}_{2}$ produced the greatest amount of carbon at $673 \mathrm{~K}$ and $873 \mathrm{~K}$; this result is consistent with the $\mathrm{XRD}$ analysis presented in Fig. 1. In addition, although $\mathrm{Ni} / \mathrm{Al}_{2} \mathrm{O}_{3}$ and $\mathrm{Ni} / \mathrm{MgO}$ were catalytically inactive at $673 \mathrm{~K}$, only a relatively minor amount of carbon was deposited on these catalysts. After raising the reaction temperature to $873 \mathrm{~K}$, a 3-fold increase in carbon deposits was observed for $\mathrm{Ni} / \mathrm{Al}_{2} \mathrm{O}_{3}$, and $\mathrm{Ni} / \mathrm{MgO}$ appeared to greatly inhibit carbon formation despite its high activity, which was, as mentioned above, comparable to that of the other catalysts.

As described in the 1. Introduction, the goal of the present study was to develop a catalyst with high activity for SRE at lower temperatures, and therefore $\mathrm{CeO}_{2}$ was selected as the most effective catalytic support because of its stimulatory effect on Ni reduction, which resulted in a relatively high activity at a lower temperature, and its inhibitory effect on carbon deposition. In the next stage, the catalytic performance of $\mathrm{CeO}_{2}$-supported $\mathrm{Co}$, $\mathrm{Cu}, \mathrm{Fe}$, and $\mathrm{Mn}$ catalysts for SRE was compared to that of $\mathrm{Ni} / \mathrm{CeO}_{2}$.

\section{2. Effect of the Transition Metal on SRE over $\mathrm{CeO}_{2}$-supported Catalysts}

\section{2. 1. Characterization of the $\mathrm{CeO}_{2}$-supported Transition Metal Catalysts before SRE}

Figures 6(b) 1-(e) 1 present the XRD patterns of the as-prepared $\mathrm{Co}, \mathrm{Cu}, \mathrm{Fe}$, and $\mathrm{Mn}$ catalysts supported on $\mathrm{CeO}_{2}$. For comparison, that of $\mathrm{Ni} / \mathrm{CeO}_{2}$ is also redisplayed in Fig. 6(a) 1. The unmarked peaks in the figure are assigned to $\mathrm{CeO}_{2}$ crystallites. XRD peaks due to $\mathrm{Co}_{3} \mathrm{O}_{4}$ and $\mathrm{CuO}$ were observed in the XRD patterns in Figs. 6(b) 1 and (c) 1, respectively. In the spectrum of $\mathrm{Fe} / \mathrm{CeO}_{2}$ (Fig. 6(d) 1), the very small peak at approximately $35.7^{\circ}$ was assigned to the reflection for the (110) lattice planes of $\alpha-\mathrm{Fe}_{2} \mathrm{O}_{3}$ crystallites. No apparent XRD peak due to Mn species was observed in the XRD pattern for $\mathrm{Mn} / \mathrm{CeO}_{2}$ shown in Fig. 6(e) 1 .

Figure 6(f) shows an enlarged view near the most intense XRD peak due to the (111) lattice planes in $\mathrm{CeO}_{2}$. As evident from the figure, only the peak for $\mathrm{Fe} / \mathrm{CeO}_{2}$ was shifted to a higher angle $\left(\sim 0.2^{\circ}\right)$; the peaks in the XRD patterns of the other catalysts were completely in accord with the $\mathrm{CeO}_{2}(111)$ reflection. Notably, the other XRD peaks due to $\mathrm{CeO}_{2}$ in the pat- 

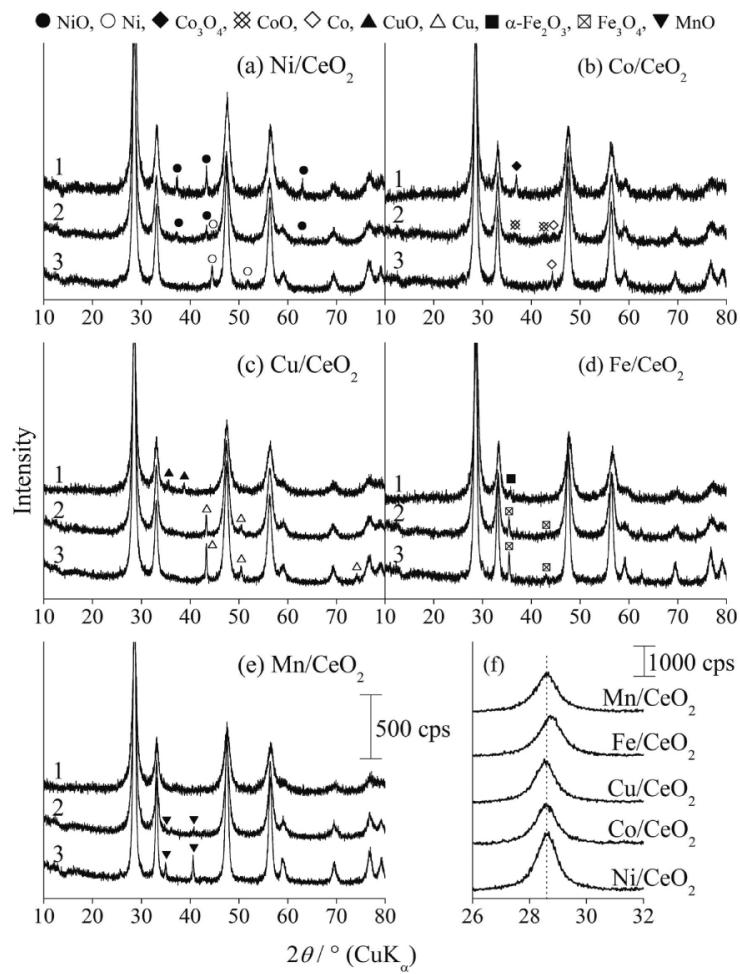

(a) $\mathrm{Ni} / \mathrm{CeO}_{2}$, (b) $\mathrm{Co} / \mathrm{CeO}_{2}$, (c) $\mathrm{Cu} / \mathrm{CeO}_{2}$, (d) $\mathrm{Fe} / \mathrm{CeO}_{2}$, and (e) $\mathrm{Mn} /$ $\mathrm{CeO}_{2}$ (1) before and (2) after SRE at $673 \mathrm{~K}$ and (3) $873 \mathrm{~K}$ for $9 \mathrm{~h}$, (f) an enlarged view of the XRD patterns of the catalysts before SRE.

Fig. 6 XRD Patterns of the $\mathrm{CeO}_{2}$-supported Transition Metal Catalysts before and after SRE

tern for $\mathrm{Fe} / \mathrm{CeO}_{2}$ were also shifted to higher angles, suggesting penetration of $\mathrm{Fe}$ ions into the $\mathrm{CeO}_{2}$ crystallites.

The surface areas of the different transition metal catalysts are summarized in Table 2 . Loading $\mathrm{CeO}_{2}$ with $\mathrm{Ni}, \mathrm{Cu}, \mathrm{Fe}$, and $\mathrm{Mn}$ resulted in a decrease in the surface area, and no change was observed for $\mathrm{Co} / \mathrm{CeO}_{2}$. $\mathrm{Fe} / \mathrm{CeO}_{2}$ had the smallest surface area. The TPR curves can be seen in Fig. 7. For $\mathrm{Co} / \mathrm{CeO}_{2}$, two peaks at $540 \mathrm{~K}$ and $594 \mathrm{~K}$ assigned to reduction of $\mathrm{Co}^{3+}$ to $\mathrm{Co}^{2+}$ and $\mathrm{Co}^{2+}$ to $\mathrm{Co}^{0}$, respectively, were observed in the TPR curve ${ }^{14)}$. Similar peaks were also observed at $530 \mathrm{~K}$ and $608 \mathrm{~K}$ for $\mathrm{Mn} / \mathrm{CeO}_{2}$. $\mathrm{Cu} / \mathrm{CeO}_{2}$ was reduced at the lowest temperature (474 K). In addition to obvious peaks below $800 \mathrm{~K}$, the $\mathrm{Ni}, \mathrm{Co}$, and $\mathrm{Cu}$ catalysts exhibited small and broad peaks at temperatures above $1000 \mathrm{~K}$, which are likely due to partial reduction in the $\mathrm{CeO}_{2}$ support. A high-temperature peak above $1000 \mathrm{~K}$ was also observed for $\mathrm{Mn} / \mathrm{CeO}_{2}$, but the hydrogen consumption of this catalyst was relatively large over a wide temperature range.

On the other hand, the TPR profile of $\mathrm{Fe} / \mathrm{CeO}_{2}$ was significantly different from that of the other catalysts: four reduction peaks were observed at 654, 767, 972, and $1120 \mathrm{~K}$. A similar TPR spectrum for an $\mathrm{Fe}-\mathrm{Ce}$

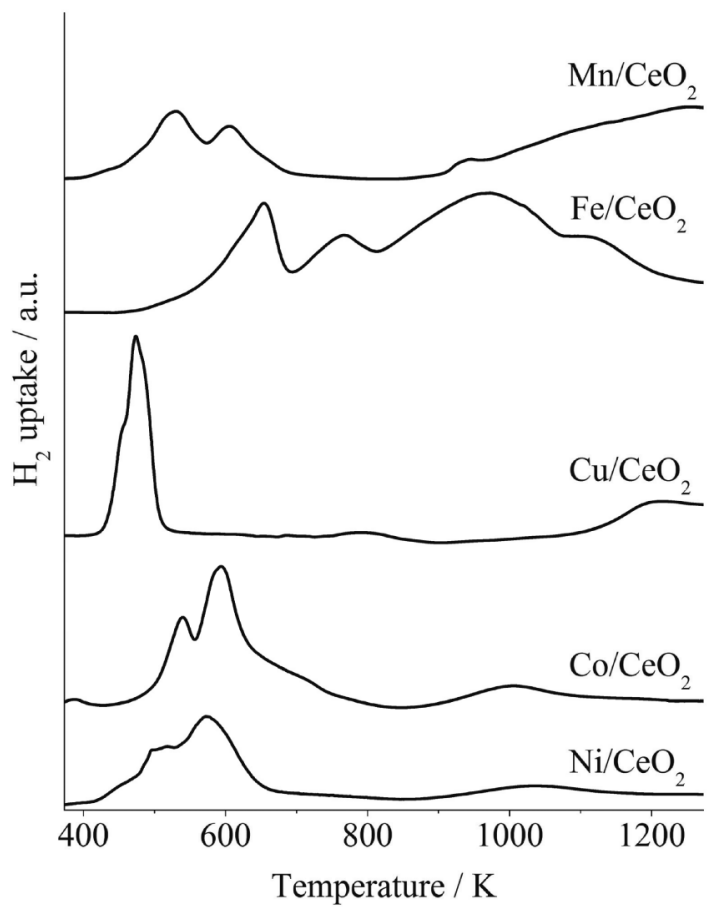

Fig. 7 TPR Profiles of the $\mathrm{CeO}_{2}$-supported Transition Metal Catalysts

mixed oxide with an Fe content of $30 \mathrm{~mol} \%$ was reported by Li et al. ${ }^{27)}$. According to these researchers, the lowest-temperature peak is due to the surface reduction of independent $\mathrm{Fe}_{2} \mathrm{O}_{3}$ dispersed on the $\mathrm{CeO}_{2}$ surface, and the second and third peaks result from the reduction of $\mathrm{Ce}^{4+}$ and $\mathrm{Fe}^{3+}$ in the surface layer of the solid solution, which is in close contact with surface iron species and to bulk reduction of $\mathrm{Fe}_{2} \mathrm{O}_{3}$ to $\mathrm{FeO}$ in the ceria lattice, respectively. The highest-temperature peak is related to the further reduction of bulk iron oxides and the consumption of isolated $\mathrm{CeO}_{2}$ particles without interaction with iron ions. The formation of an $\mathrm{Fe}-\mathrm{Ce}-\mathrm{O}$ solid solution in $\mathrm{Fe} / \mathrm{CeO}_{2}$ is also supported by its smaller surface area and the shift of the XRD peaks due to $\mathrm{CeO}_{2}{ }^{28), 29)}$.

\section{2. 2. SRE over the $\mathrm{CeO}_{2}$-supported Transition Metal Catalysts}

Figure 8 shows the results of TP-SRE over the $\mathrm{CeO}_{2}$-supported transition metal catalysts. The most easily reduced $\mathrm{Cu}$ catalyst began to produce $\mathrm{H}_{2}$ at the lowest temperature $(523 \mathrm{~K})$, and the other catalysts required higher reaction temperatures for $\mathrm{H}_{2}$ generation. Although $\mathrm{Ni} / \mathrm{CeO}_{2}$ and $\mathrm{Co} / \mathrm{CeO}_{2}$ exhibited low activities below $650 \mathrm{~K}$, the yields of $\mathrm{H}_{2}$ and $\mathrm{CO}_{2}$ increased rapidly and exceeded those of $\mathrm{Cu} / \mathrm{CeO}_{2}$ at $673 \mathrm{~K}$. Notably, the Ni catalyst led to the production of a larger quantity of $\mathrm{CH}_{4}$ than the other metals above $700 \mathrm{~K}$. In addition, the catalytic activity of $\mathrm{Fe} / \mathrm{CeO}_{2}$ and $\mathrm{Mn} / \mathrm{CeO}_{2}$ increased above $650 \mathrm{~K}$ and was approximately the same as that of $\mathrm{Cu} / \mathrm{CeO}_{2}$ at $873 \mathrm{~K}$. 


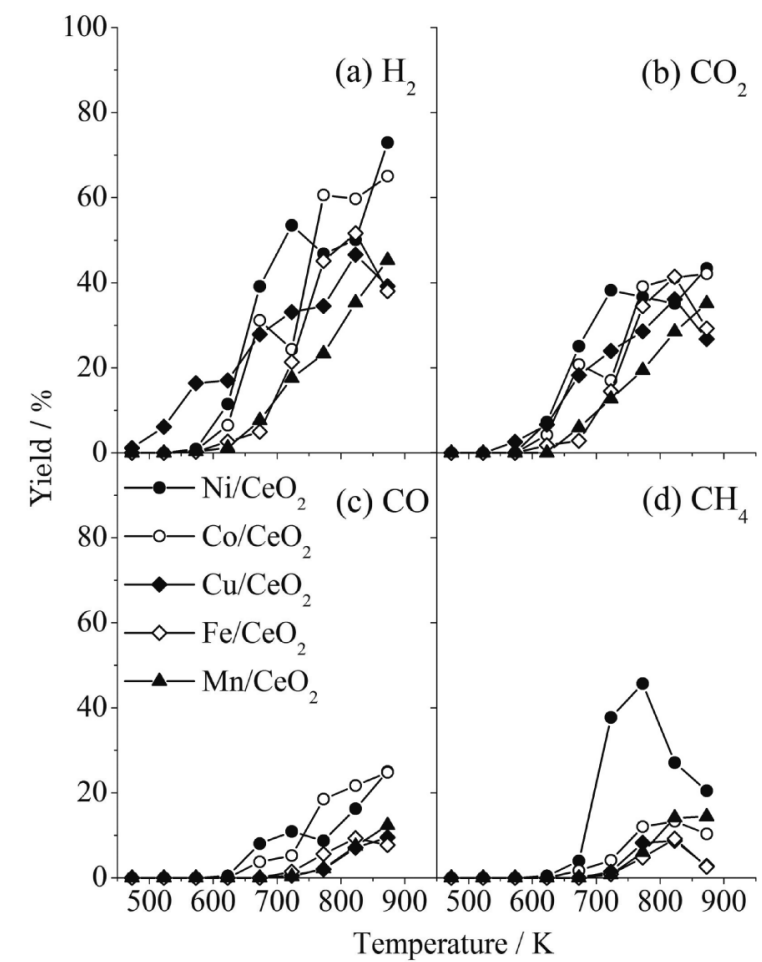

Fig. 8 Product Yields for Temperature-programmed SRE over the $\mathrm{CeO}_{2}$-supported Transition Metal Catalysts

The yields of $\mathrm{H}_{2}, \mathrm{CO}_{2}, \mathrm{CO}$, and $\mathrm{CH}_{4}$ during isothermal SRE at a reaction time of $9 \mathrm{~h}$ are shown in Fig. 9. The catalytic activity of the $\mathrm{Fe}$ and $\mathrm{Mn}$ catalysts was relatively low. At $673 \mathrm{~K}, \mathrm{Ni} / \mathrm{CeO}_{2}$ exhibited the highest $\mathrm{H}_{2}$ and $\mathrm{C} 1$-gas yields, followed by $\mathrm{Co} / \mathrm{CeO}_{2}$ and $\mathrm{Cu} /$ $\mathrm{CeO}_{2}$. The Ni catalyst was also characterized by the production of a large amount of $\mathrm{CH}_{4}$, as expected from Fig. 8. By raising the reaction temperature to $873 \mathrm{~K}$, the catalytic activity of $\mathrm{Ni} / \mathrm{CeO}_{2}$ and $\mathrm{Co} / \mathrm{CeO}_{2}$ was significantly enhanced, and the $\mathrm{Cu} / \mathrm{CeO}_{2}$ catalyst became less active. In addition, the $\mathrm{H}_{2}$ and $\mathrm{CO}_{2}$ yields over $\mathrm{Cu} / \mathrm{CeO}_{2}$ at $673 \mathrm{~K}$ were nearly the same as those during TP-SRE, but at $873 \mathrm{~K}$ were much smaller than those at the same temperature during TP-SRE (Fig. 8). This result is likely due to deactivation by carbon deposition during the long-term reaction at $873 \mathrm{~K}$.

To verify this speculation, changes in the yields during $\mathrm{SRE}$ over $\mathrm{Ni} / \mathrm{CeO}_{2}$ and $\mathrm{Cu} / \mathrm{CeO}_{2}$ at $873 \mathrm{~K}$ as a function of reaction time and the effects of catalyst regeneration using air were investigated. The results are illustrated in Fig. 10. For the $\mathrm{Ni} / \mathrm{CeO}_{2}$ catalyst, the $\mathrm{H}_{2}$ and $\mathrm{C} 1$ gas yields remained constant at approximately $70 \%$ and $90 \%$, respectively, for $5 \mathrm{~h}$, which were in approximate agreement with the values at $9 \mathrm{~h}$ in Fig. 9 with an uncertainty of $10 \%$. The catalytic performance also remained constant after the catalyst was exposed to an air flow at $873 \mathrm{~K}$ for $1 \mathrm{~h}$. On the other hand, the $\mathrm{H}_{2}$ and $\mathrm{C} 1$-gas yields over the $\mathrm{Cu} / \mathrm{CeO}_{2}$ catalyst were $52 \%$ and $68 \%$, respectively, during the first $30 \mathrm{~min}$, but

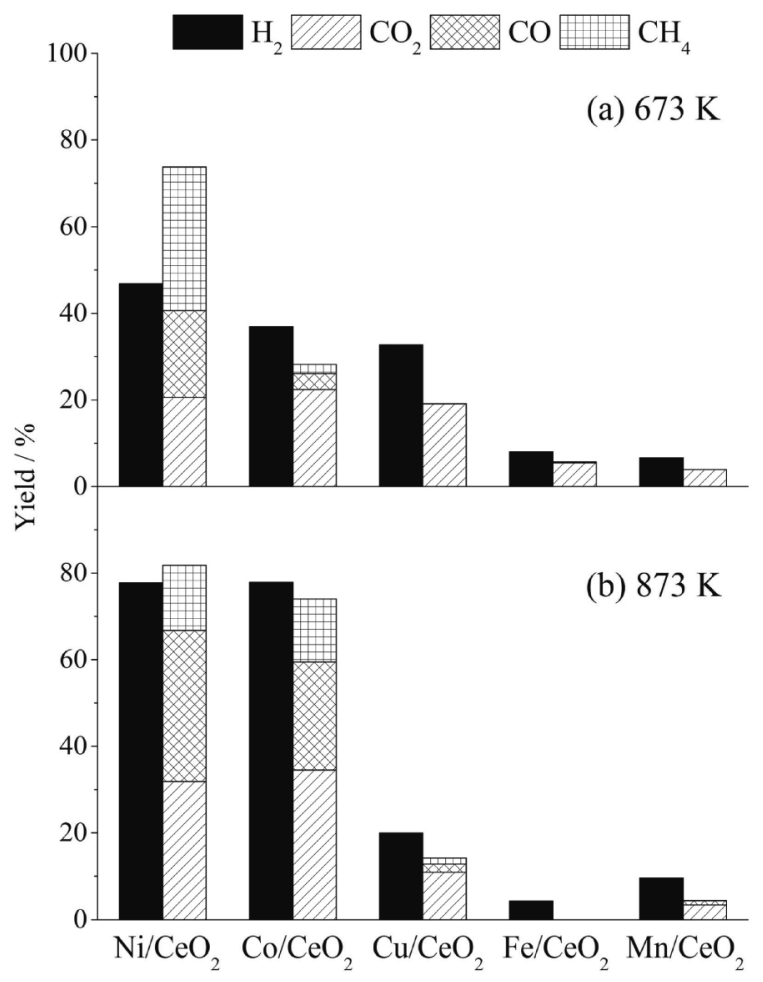

Fig. 9 Product Yields at $9 \mathrm{~h}$ after the Initiation of SRE at (a) $673 \mathrm{~K}$ and (b) $873 \mathrm{~K}$ over the $\mathrm{CeO}_{2}$-supported Transition Metal Catalysts

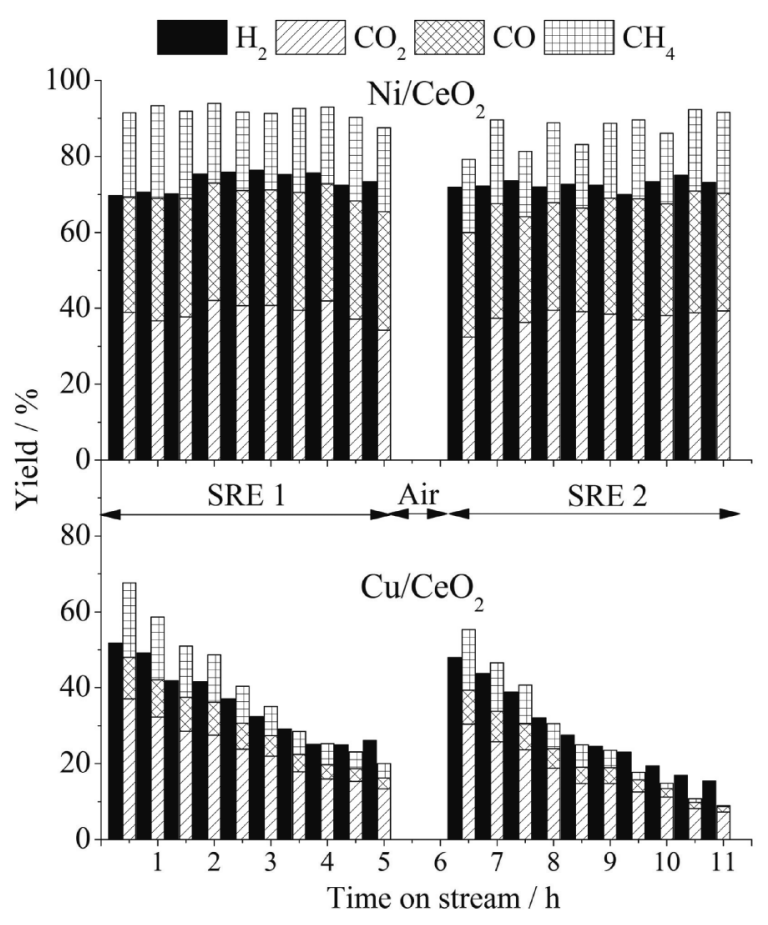

Fig. 10 Change in the SRE Yield over $\mathrm{Ni} / \mathrm{CeO}_{2}$ and $\mathrm{Cu} / \mathrm{CeO}_{2}$ at $873 \mathrm{~K}$ and the Effects of Catalyst Regeneration Using Air

decreased to $26 \%$ and $20 \%$, respectively, after $5 \mathrm{~h}$. While the catalytic activity was recovered following air 
treatment at $873 \mathrm{~K}$, the catalyst was deactivated during the second SRE run in the same manner as observed in the first run. Similar deactivation was also observed for $\mathrm{Fe} / \mathrm{CeO}_{2}$ and $\mathrm{Mn} / \mathrm{CeO}_{2}$. These results lead to the conclusion that the carbon deposited on $\mathrm{Cu}, \mathrm{Fe}$, and $\mathrm{Mn}$ greatly inhibited SRE, and carbon deposition on $\mathrm{Ni}$ / $\mathrm{CeO}_{2}$ did not influence the reaction.

\section{2. 3. Characterization of the $\mathrm{CeO}_{2}$-supported Transition Metal Catalysts after SRE}

The XRD patterns of the $\mathrm{CeO}_{2}$-supported catalysts after SRE at $673 \mathrm{~K}$ and $873 \mathrm{~K}$ are shown in Figs. 6(a) 2-(e) 2 and (a) 3-(e) 3, respectively. The unmarked peaks due to $\mathrm{CeO}_{2}$ increased in intensity compared with those observed in the XRD patterns in Figs. 6(a) 1-(e) 1, indiating the growth of $\mathrm{CeO}_{2}$ crystallites during SRE. In Fig. 6(b), it can be seen that the $\mathrm{Co}_{2} \mathrm{O}_{3}$ in the asprepared Co catalyst was reduced to $\mathrm{CoO}$ and $\mathrm{Co}$ metal during SRE at $673 \mathrm{~K}$ and completely reduced to the metal at $873 \mathrm{~K}$. It is also evident from Fig. 6(c) that the $\mathrm{CuO}$ on $\mathrm{CeO}_{2}$ was fully reduced to metallic $\mathrm{Cu}$, even at $673 \mathrm{~K}$. Two small peaks due to $\mathrm{MnO}$ appeared at $34.9^{\circ}$ and $40.6^{\circ}$ in the XRD pattern of $\mathrm{Mn} / \mathrm{CeO}_{2}$ after SRE at $673 \mathrm{~K}$ (Fig. 6(e) 2) and increased in intensity after SRE at $873 \mathrm{~K}$, but no XRD peak for metallic Mn was observed (Fig. 6(e) 3). It was therefore concluded that the two TPR peaks for $\mathrm{Mn} / \mathrm{CeO}_{2}$ at $530 \mathrm{~K}$ and $608 \mathrm{~K}$ in Fig. 7 were not due to the reduction of manganese ions to the metal, which likely requires higher temperatures than $1000 \mathrm{~K}$, as suggested by the highertemperature TPR peak in Fig. 7.

In the case of $\mathrm{Fe} / \mathrm{CeO}_{2}$, the small peak at $35.7^{\circ}$ in the XRD pattern in Fig. 6(d) 1 disappeared, and two peaks appeared at $35.5^{\circ}$ and $43.1^{\circ}$ after SRE at $673 \mathrm{~K}$ (Fig. 6(d) 2), whose intensities increased when the reaction temperature was raised to $873 \mathrm{~K}$ (Fig. 6(d) 3 ). These peaks were assigned to the diffractions of the (311) and (400) planes of $\mathrm{Fe}_{3} \mathrm{O}_{4}$ lattices. In addition, the shift of the XRD peaks due to $\mathrm{CeO}_{2}$ (Fig. 6(d) 1) was no longer detected after the reaction. These results indicated that the $\mathrm{Fe}-\mathrm{Ce}-\mathrm{O}$ solid solution in the asprepared $\mathrm{Fe} / \mathrm{CeO}_{2}$ catalyst was decomposed to $\mathrm{Fe}_{3} \mathrm{O}_{4}$ and $\mathrm{CeO}_{2}$ in the reductive atmosphere.

TG profiles of the catalysts employed for SRE at $673 \mathrm{~K}$ and $873 \mathrm{~K}$ for $9 \mathrm{~h}$ are shown in Fig. 11, and the quantities of carbon deposits estimated from the weight losses are summarized in Table 2. $\mathrm{Ni} / \mathrm{CeO}_{2}$ and $\mathrm{Co} /$ $\mathrm{CeO}_{2}$ after SRE at $673 \mathrm{~K}$ contained a relatively large amount of deposited carbon that required higher temperatures for burning than the other catalysts. In addition, after reaction at $873 \mathrm{~K}$, the burning temperatures of the carbon deposited on the catalytically-active $\mathrm{Ni}$ and Co catalysts clearly increased, and those of the other catalysts remained nearly unchanged. Furthermore, the carbon content of $\mathrm{Ni} / \mathrm{CeO}_{2}$ increased by approximately $30 \%$, whereas $\mathrm{Co} / \mathrm{CeO}_{2}$ showed a decrease in the carbon content which may be attributable to the significant increases in $\mathrm{C} 1$ gases. Finally, the inactive $\mathrm{Cu}, \mathrm{Fe}$, and $\mathrm{Mn}$ catalysts maintained a low level of carbon deposition.

Figure 12 shows the SEM images of the $\mathrm{CeO}_{2}$ supported $\mathrm{Ni}, \mathrm{Co}$, and $\mathrm{Cu}$ catalysts after $\mathrm{SRE}$ at $873 \mathrm{~K}$ for $9 \mathrm{~h}$. $\mathrm{Ni} / \mathrm{CeO}_{2}$ and $\mathrm{Co} / \mathrm{CeO}_{2}$ produced carbon fibers with a diameter of 20-70 nm and 10-30 nm, respectively. On the other hand, no obviously-carbonaceous matter was observed on the surface of $\mathrm{Cu} / \mathrm{CeO}_{2}$. Therefore, it can be concluded from Figs. 10, 11, and 12 that a minor amount of carbon deposits covered the metallic $\mathrm{Cu}$ sites, resulting in a remarkable decrease in the activity of $\mathrm{Cu} / \mathrm{CeO}_{2}{ }^{30)}$ 32). In contrast, the long-term stability of $\mathrm{Ni} / \mathrm{CeO}_{2}$ suggests that the fibers of the deposited carbons had a porous structure through which the reac-

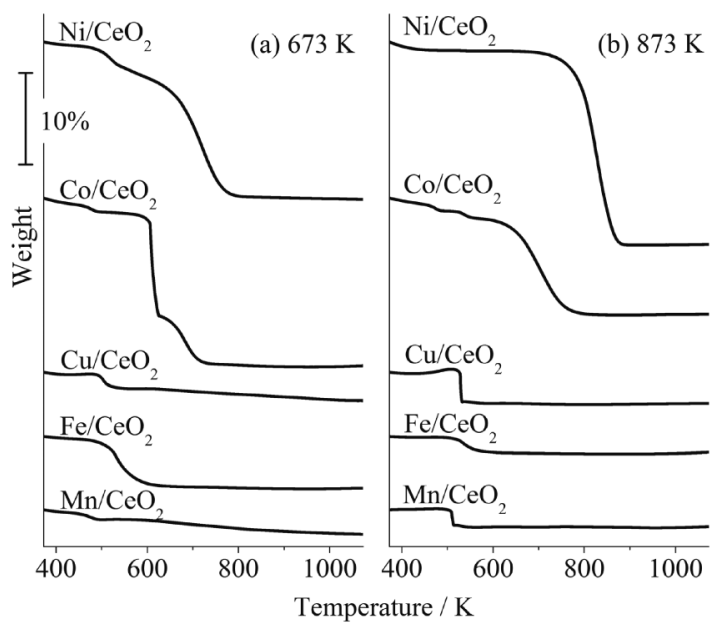

Fig. 11 TG Profiles of the $\mathrm{CeO}_{2}$-supported Transition Metal Catalysts after SRE at $673 \mathrm{~K}$ and $873 \mathrm{~K}$ for $9 \mathrm{~h}$

Table 2 BET Surface Areas of the $\mathrm{CeO}_{2}$-supported Catalysts and the Amount of Deposited Carbon after SRE at $673 \mathrm{~K}$ and $873 \mathrm{~K}$ for $9 \mathrm{~h}$

\begin{tabular}{lccc}
\hline \multirow{2}{*}{ Catalyst } & Surface area $\left[\mathrm{m}^{2} \mathrm{~g}^{-1}\right]$ & \multicolumn{2}{c}{ Carbon deposit $\left[\mathrm{g} \mathrm{g}_{\text {-cat }}{ }^{-1}\right]$} \\
\cline { 3 - 4 } & & SRE at $673 \mathrm{~K}$ & SRE at $873 \mathrm{~K}$ \\
\hline $\mathrm{Ni} / \mathrm{CeO}_{2}$ & 100 & 0.21 & 0.28 \\
$\mathrm{Co} / \mathrm{CeO}_{2}$ & 110 & 0.22 & 0.14 \\
$\mathrm{Cu} / \mathrm{CeO}_{2}$ & 75 & 0.03 & 0.03 \\
$\mathrm{Fe} / \mathrm{CeO}_{2}$ & 70 & 0.06 & 0.02 \\
$\mathrm{Mn} / \mathrm{CeO}_{2}$ & 80 & 0.03 & 0.02 \\
\hline
\end{tabular}




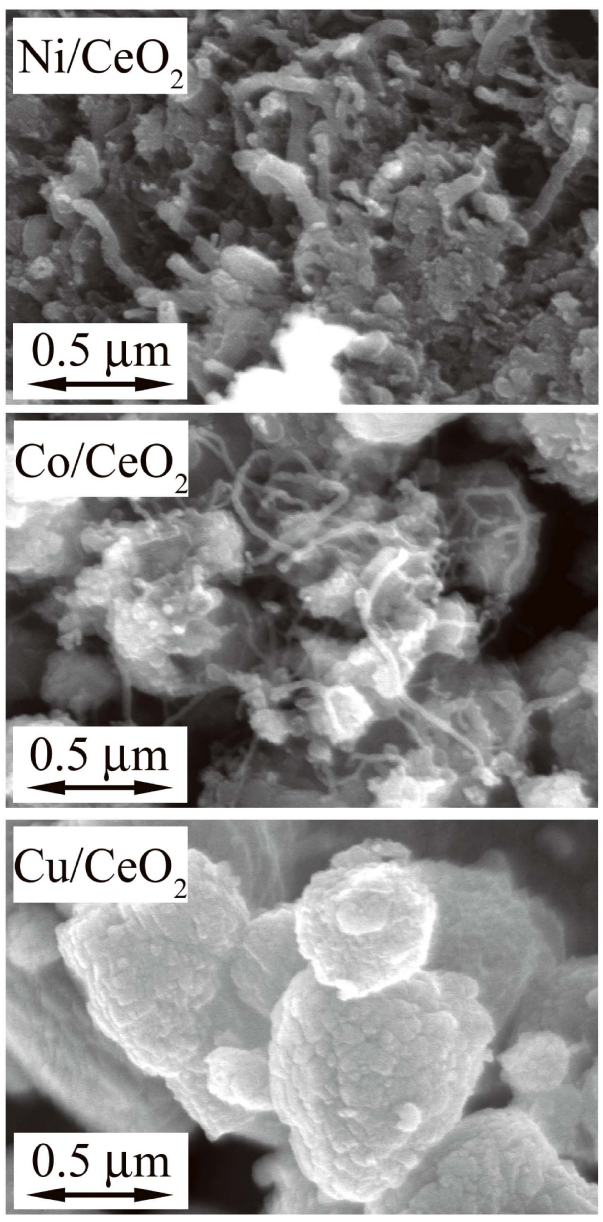

Fig. 12 SEM Images of the $\mathrm{CeO}_{2}$-supported $\mathrm{Ni}, \mathrm{Co}$, and $\mathrm{Cu}$ Catalysts after SRE at $873 \mathrm{~K}$ for $9 \mathrm{~h}$

tants could pass, enabling contact with metallic $\mathrm{Ni}$ sites $^{30)}$

\section{Conclusion}

The effects of the metal oxide support and first row transition metal catalyst on SRE were investigated. Because the catalytic sites for SRE are reduced metallic crystallites, the reducibility of the transition metals strongly affected their low-temperature activity. The $\mathrm{CeO}_{2}$ support promoted the reduction of $\mathrm{NiO}$ crystallites to the metal, resulting in a higher activity at a low temperature. In contrast, $\mathrm{Al}_{2} \mathrm{O}_{3}$ and $\mathrm{MgO}$ partly formed solid solutions with $\mathrm{Ni}$ and consequently hindered its reduction and catalytic activity. $\mathrm{ZrO}_{2}$ - and $\mathrm{SiO}_{2}$-supported $\mathrm{Ni}$ catalysts had a similar level of activity as the $\mathrm{CeO}_{2}$-supported $\mathrm{Ni}$ catalyst at $673 \mathrm{~K}$, but larger amounts of carbon deposits were formed with these systems, and therefore $\mathrm{CeO}_{2}$ was adopted as the support.

$\mathrm{Fe} / \mathrm{CeO}_{2}$ and $\mathrm{Mn} / \mathrm{CeO}_{2}$ required relatively high temperatures for reduction of the metal and were less active. $\mathrm{Cu}$ on $\mathrm{CeO}_{2}$ was reduced at the lowest temperature and exhibited the highest activity below $650 \mathrm{~K}$, but was remarkably deactivated by a minor amount of carbon deposition at a reaction temperature of $873 \mathrm{~K}$. Although $\mathrm{Co} / \mathrm{CeO}_{2}$ exhibited activities as high as that of $\mathrm{Ni} / \mathrm{CeO}_{2}$ at $873 \mathrm{~K}$, the latter afforded higher yields of $\mathrm{H}_{2}$ and $\mathrm{C} 1$ gases at $673 \mathrm{~K}$. In conclusion, $\mathrm{Ni} / \mathrm{CeO}_{2}$ exhibited both high catalytic activity and long-term stability for low-temperature SRE, despite the deposition of a large quantity of fibrous carbon.

\section{References}

1) Dunn, S., Int. J. Hydrogen Energ., 27, (3), 235(2002).

2) Ni, M., Leung, D. Y. C., Leung, M. K. H., Int. J. Hydrogen Energ., 32, (15), 3238 (2007).

3) Fatsikostas, A. N., Kondarides, D. I., Verykios, X. E., Catal. Today, 75, (1-4), 145 (2002).

4) Haryanto, A., Fernando, S., Murali, N., Adhikari, S., Energy \& Fuels, 19, (5), 2098 (2005).

5) Vaidya, P. D., Rodrigues, A. E., Chem. Eng. J., 117, (1), 39 (2006).

6) Ye, J. L., Wang, Y. Q., Liu, Y., Wang, H., Int. J. Hydrogen Energ., 33, (22), 6602 (2008).

7) Zhang, B., Tang, X., Li, Y., Xu, Y., Shen, W., Int. J. Hydrogen Energ., 32, (13), 2367 (2007).

8) Huang, Y. H., Wang, S. F., Tsai, A. P., Kameoka, S., Ceram. Int., 40, (3), 4541 (2014).

9) Jones, S. D., Hagelin-Weaver, H. E., Appl. Catal. B: Environmental, 90, (1-2), 195 (2009).

10) Pérez-Hernández, R., Gutiérrez-Martínez, A., Gutiérrez-Wing, C. E., Int. J. Hydrogen Energ., 32, (14), 2888 (2007).

11) Urasaki, K., Fukuda, Y., Sekine, Y., Matsukata, M., Kikuchi, E., J. Jpn. Petrol. Inst., 51, (2), 83 (2008).

12) Nagai, M., Akiyama, M., Oki, Y., J. Jpn. Petrol. Inst., 55, (1), 67 (2012).

13) Sun, J., Qiu, X. P., Wu, F., Zhu, W. T., Int. J. Hydrogen Energ., 30, (4), 437 (2005).

14) Pang, X., Chen, Y., Dai, R., Cui, P., Chin. J. Catal., 33, (2), 281 (2012).

15) Haga, F., Nakajima, T., Miya, H., Mishima, S., Catal. Lett., 48, (3-4), 223 (1997).

16) Casanovas, A., Llorca, J., Homs, N., Fierro, J. L. G., Piscina, P. R., J. Mol. Catal. A: Chem., 250, (1-2), 44 (2006).

17) Erdöhelyi, A., Raskó, J., Kecskés, T., Tóth, M., Dömök, M., Baán, K., Catal. Today, 116, (3), 367 (2006).

18) Ciambelli, P., Palma, V., Appl. Catal. B: Environmental, 96, (12), 190 (2010).

19) Alberton, A. L., Souza, M. M. V. M., Schmal, M., Catal. Today, 123, (1-4), 257 (2007).

20) Sanchez-Sanchez, M. C., Navarro, R. M., Fierro, J. L. G., Int. J. Hydrogen Energ., 32, (10-11), 1462 (2007).

21) Trane-Restrup, R., Dahl, S., Jensen, A. D., Int. J. Hydrogen Energ., 38, (35), 15105 (2013).

22) Cai, W., Wang, F., Zhan, E., Van Veen, A. C., Mirodatos, C., Shen, W., J. Catal., 257, (1), 96 (2008).

23) Hadjiivanov, K., Mihaylov, M., Klissurski, D., Stefanov, P., Abadjieva, N., Vassileva, E., Mintchevz, L., J. Catal., 185, (2), 314 (1999).

24) Frusteri, F., Freni, S., Chiodo, V., Spadaro, L., Blasi, O. D., Bonura, G., Cavallaro, S., Appl. Catal. A: General, 270, (1-2), 1 (2004).

25) Zanganeh, R., Rezaei, M., Zamaniyan, A., Int. J. Hydrogen Energ., 38, (7), 3012 (2013). 
26) Yamazaki, O., Tomishige, K., Fujimoto, K., Appl. Catal. A: General, 136, (1), 49 (1996).

27) Li, K., Haneda, M., Ning, P., Wang, H., Ozawa, M., Appl. Surf. Sci., 289, 378 (2014).

28) Li, G., Smith, R. L., Inomata, H., J. Am. Chem. Soc., 123, (44), 11091 (2001).

29) Pérez-Alonso, F. J., Granados, M. L., Ojeda, M., Terreros, P., Rojas, S., Herranz, T., Fierro, J. L. G., Gracia, M., Gancedo, J.
R., Chem. Mater., 17, (9), 2329 (2005).

30) Vicente, J., Montero, C., Ereña, J., Azkoiti, M. J., Bilbao, J., Gayubo, A. G., Int. J. Hydrogen Energ., 39, (24), 12586 (2014).

31) Djinović, P., Črnivec, I. G. O., Erjavec, B., Pintar, A., Appl. Catal. B: Environmental, 125, 259 (2012).

32) Wang, F., Li, Y., Cai, W., Zhan, E., Mu, X., Shen, W., Catal. Today, 146, (1-2), 31 (2009).

要旨

\section{エタノール水蒸気改質による水素製造における金属酸化物担体と非貴金属活性種の効果}

佐伯 貴紀, 大北 博宣, 角田 範義, 水嶋 生智

豊橋技術科学大学環境・生命工学系, 441-8580 愛知県豊橋市天伯町字雲雀ヶ丘1-1

エタノール水蒸気改質による水素製造における金属酸化物担 体と第一遷移金属触媒の影響を検討した。 $\mathrm{CeO}_{2}$ 担体上の $\mathrm{Ni}$ は $\mathrm{ZrO}_{2}, \mathrm{SiO}_{2}, \mathrm{Al}_{2} \mathrm{O}_{3}, \mathrm{MgO}$ 担体上の $\mathrm{Ni}$ よりも容易に還元され, より低温で水素を生成した。また, $\mathrm{Ni} / \mathrm{CeO}_{2}$ 触媒は反応温度 $673 \mathrm{~K}$ において高い活性を維持するとともに炭素の析出を抑制 した。以後, 担体として $\mathrm{CeO}_{2}$ を用いることとした。 $\mathrm{Ni} / \mathrm{CeO}_{2}$
と比べると $\mathrm{Fe} / \mathrm{CeO}_{2}$ や $\mathrm{Mn} / \mathrm{CeO}_{2}$ は不活性であった。 $\mathrm{Co} / \mathrm{CeO}_{2}$ は $673 \mathrm{~K}$ ではわずかに活性が低かったが, $873 \mathrm{~K}$ では同等の水素 収率を示した。 $\mathrm{Cu} / \mathrm{CeO}_{2}$ は還元されやすく, より低温で水素を 生成し始めたが, 炭素析出により活性は次第に低下した。した がって, $\mathrm{Ni} / \mathrm{CeO}_{2}$ は $673 \mathrm{~K}$ での最高水素収率と長時間安定性を 有する最良の組み合わせであると結論した。 